\title{
7 Georgia's Two Others: Nationalism and the Identity Struggle of a Post-Soviet Nation State
}

\section{Introduction}

Georgia is one of the countries where identity crises and nationalism have led to significant problems and caused political, social, and territorial disintegration during the first years of independence in the 1990s. Later the situation changed: along with Western aspirations, the Georgian national project gradually acquired civil features. The present contribution analyzes the symbolic and real roles of the West in the formation of post-Soviet Georgian public discourse(s) and the importance of attitudes to the West in the development of diverse forms of national identity.

At the end of the 1980s, the country's independence became the foremost goal of the national movement that started in the Soviet Republic of Georgia. After achieving this goal and the establishment of independence, at the beginning of the 1990s, the development of an independent democratic state became the most significant challenge for Georgian society. In the process of deconstructing the Soviet system, Georgians started to construct a new identity and searched for their own place within the international system. Since this period, the idea of the European origin of Georgians and their close links to the West has become widespread in the public and academic circles. ${ }^{1}$ The idea of "belonging to Europe" still plays a key role in the process of formation of the Georgian identity. However, the attitude to the West is not positive in all cases. Although Euro-Atlantic integration on the political level is the key message of the Georgian national project, a certain portion of Georgian society is filled with fear and mistrust of the West. Diverse social groups demonize the West, although, unlike in the Soviet era, in this case the "Western Demon" does not threaten the "Soviet motherland." Instead, it threatens a traditional orthodox country with an ancient history. This contribution aims to study two different,

1 Frederik Coene, Euro-Atlantic Discourse in Georgia: The Making of Georgian Foreign and Domestic Policy After the Rose Revolution (London/New York: Routledge, 2016), 31.

Note: This work was supported by the Shota Rustaveli National Science Foundation of Georgia under Grant [YS-18-1461].

Ә Open Access.@ 2021 Irakli Chkhaidze, published by De Gruyter. (cc) BY-NC-ND This work is licensed under the Creative Commons Attribution-NonCommercial-NoDerivatives 4.0 International License. 
opposing, yet interlinked tendencies that are widespread in the process of the post-socialist transformation of Georgia.

Identity and nationalism studies is a relatively new research field within the humanities and social sciences in Georgia. In this regard, many problematic issues should be viewed using contemporary theoretical and methodological attitudes. There are only a few works focusing on the given problem from an academically intriguing perspective. ${ }^{2}$ Although the empirical material is rich and diverse, its major portion has not been systematized and contextualized based on a certain theoretical framework. This reality proves the significance of the problem under analysis.

From the literature which forms the direct theoretical grounds of the present research, above all, mention should be made of Rogers Brubaker's works. In his work Ethnicity Without Groups, the author considers ethnicity, nations, and group identities of various types as construed phenomena. According to Brubaker, when researching nations and ethnic groups, attention should be focused on practical categories, situations, cultural idioms, discourse, political projects, and the changing nature of group membership; phenomena like ethnicity, nation, and race are results of the social and political processes characteristic of the contemporary epoch. A separate chapter of Brubaker's work is dedicated to the dichotomy of ethnic and civil nationalism. The author mentions that similar classifications are often accompanied by analytical and normative ambiguity and geographical determinism, which undoubtedly deserves criticism. Despite this, Brubaker shares the key postulates defining ethnic and civil nationalism. ${ }^{3}$

Other significant works are included in the collection After Independence: The Making and Protection of the Nation in Postcolonial and Postcommunist States, edited by Lowell W. Barrington. The book embraces discussions of various post-socialist states, including Georgia. ${ }^{4}$ In the introduction of the book, the editor speaks about an important objective of research into nationalism in the post-socialist epoch, namely the study of the role and function of nationalism after it has reached its main goal, i.e. the formation of a sovereign state.

2 Selected works on the issues: Ronald Grigor Suny, The Making of the Georgian Nation, 2nd ed. (Bloomington, IN: Indiana University Press, 1994); Jonathan Wheatley, Georgia from National Awakening to Rose Revolution: Delayed Transition in the Former Soviet Union (London/ New York: Routledge, 2005); Stephen F. Jones, Socialism in Georgian Colors: The European Road to Social Democracy, 1883-1917 (Cambridge, MA: Harvard University Press, 2005).

3 Rogers Brubaker, Ethnicity without Groups (Cambridge, MA: Harvard University Press, 2006), $27-87$.

4 Stephen F. Jones, “Georgia: Nationalism from under the Rubble," in After Independence: The Making and Protection of the Nation in Postcolonial and Postcommunist States, ed. Lowell W. Barrington (Ann Arbor, MI: University of Michigan Press, 2006), 248-276. 
The author in addition thoroughly analyzes contemporary debates around the issues of nation and nationalism. ${ }^{5}$

The conceptual frame of the research partly embraces a phenomenon of populism and its theoretical considerations. The study consequently benefits from the famous book The People by Margaret Canovan. Discussing difficulties regarding the generalization and contextualization of populist movements, the author claims that ideological movements like socialism, liberalism, or nationalism gained a degree of coherence from a continuous history, willingness on the part of most followers to identify themselves by the name, and distinctive principles and policies. "Populism does not fit this pattern. There is no acknowledged common history, ideology, programme or social base, and the term is usually applied to movements from outside, often as a term of abuse."6

This work focuses on the role of a national leader in national populist discourses. In this respect, The Global Rise of Populism: Performance, Political Style, and Representation by Benjamin Moffit was found to be very helpful. In the chapter devoted to a leader as a major performer in populist discourses, the author asks important questions regarding populist performers, their audience, and the respective interactions. ${ }^{7}$ First of all, populism is a political style aiming to mobilize the people around certain ideas. Post-Soviet Georgia is a field of struggle between pro-Western and anti-Western populist discourses with an explicit role for leaders. Moffit concludes that populist leaders should be seen as key performers of populism: "It is the populist leader who inspires hope in followers, anxiety and panic in detractors, and who attracts the attention of the all-important media through which they broadcast their appeal to 'the people."” ${ }^{8}$ More reflections on the phenomenon of populism will be presented in the section dedicated to the theoretical framework of the research.

There are only a few works in the Georgian language dedicated to the issues of post-Soviet nationalism, populism, and the formation of identity. The field of social sciences is not rich in fundamental research regarding the above-mentioned issues. The reason for this is probably that in the Soviet Union, under the conditions of a strict ideological regime, the study of the given problem was very restricted and only possible when based on a Marxist-Leninist attitude. In the post-Soviet epoch,

5 Lowell W. Barrington. "Nationalism \& Independence," in After Independence: The Making and Protection of the Nation in Postcolonial and Postcommunist States, ed. Lowell W. Barrington (Ann Arbor, MI: University of Michigan Press, 2006), 3-30.

6 Margaret Canovan, The People (Cambridge: Polity Press, 2005), 79.

7 Benjamin Moffitt, The Global Rise of Populism: Performance, Political Style, and Representation (Stanford: Stanford University Press, 2016), 51-69.

8 Ibid., 68. 
despite the absence of ideological pressure, the old attitudes to academic research have been preserved. This proves the necessity of research from a new perspective.

It is necessary to distinguish several works from the literature directly focusing on the issue under analysis. In this regard, mention should be made of Stephen Jones' Georgia: A Political History since Independence. A chapter of this book is dedicated to a discussion of Georgian populism. ${ }^{9}$ Mention should also be made of Adrian Brisku's article "So Far and Yet So Near, The Image of Europe in Georgia: History of Ideas." ${ }^{, 10}$ In the historical dynamics, this work analyzes the problem of Georgia's attitude to the West. The historical background is also discussed in Ghia Nodia's "The Idea of the West in the Georgian Consciousness"11 and Tamar Kakitelashvili's "The West in the Georgian Consciousness." 12

The issue under analysis is part of the recent history of Georgia. The processes that took place in the given period largely defined Georgia's internal and international state and led to the successes and failures in the period of transition after independence. At the current stage of development, it is of crucial importance to implement a critical analysis of Georgia's history since its independence. The study of the processes from the perspective of identity research will help to reevaluate the recent past and define the regional and international contexts of events that have taken place in Georgia.

The empirical grounds for the given research embrace public speeches of representatives of the political and intellectual elite, addresses, interviews, and academic and journalistic works. The post-Soviet Georgian public discourse is a construed phenomenon, developed by the elite and largely transformed in the past decades. The main goal of the project is to observe the stages of the abovementioned transformation and analyze their dynamics.

The research that the present contribution is based on aims at the study of the formation and development of the Georgian national project from the viewpoint of attitudes to the Western space. The contribution also aims to analyze the factors conditioning the formation of two opposing national narratives. The study is focused on the contradictory nature of the Western orientation of post-

9 Stephen F. Jones, Georgia: A Political History since Independence (London: I.B. Tauris, 2013), 51-73.

10 Adrian Brisku, "So Far and Yet So Near, The Image of Europe in Georgia: History of Ideas," May 5, 2017, https://ge.boell.org/ka/2017/05/05/ase-shors-da-mainc-ase-axlos-evropis-saxexati-sakartveloshi-ideata-istoria

11 Ghia Nodia, "The Idea of the West in the Georgian Consciousness," Society and Politics 2 (1999): 35-74.

12 Tamar Kakitelashvili, “The West in the Georgian Consciousness," Language and Culture 1 (2000): 47-54. 
Soviet Georgia. The irreversible Western orientation was formed against the background of complicated social processes in the past decades. This can be proved by recent events in Georgia, which reflect the simultaneous processes of the idealization and demonization of the West. This tendency is due to different narratives developed since independence. An analysis of the dynamics of these narratives will explain the controversial attitudes of Georgian society to the West.

Since the end of the 1980s, when the national movement became dominant in the Georgian social space, its key aim was to define the attitude to the West. In the period of Georgia's independence, this issue did not lose its importance; on the contrary, it became more topical and, parallel to political contacts with the West, it turned into a specific problem for Georgian society. The West turned into a source that equally "fed" Georgian orthodox, ultra-nationalist, and liberal-democratic narratives formed in the public discourse. Demonization and idealization of the West have become the most successful means for manipulating public opinion and acquiring political legitimization. The concrete purpose of this paper is to analyze, systematize, and contextualize the empirical material, which clearly reflects the opposing viewpoints in the public space. Based on a preliminary hypothesis, we can assume that, despite radical opposition, the above-mentioned narratives are closely interlinked and make each other topical. Thus, in order to draw a vivid picture, we should analyze them jointly against the background of Georgia's post-Soviet transformation.

\section{Theoretical Basis and Methodology}

Contemporary Western scientific circles (e.g. Stephen Jones in his monograph on Georgia) outline the shortage of theoretical attitudes that would enable a thorough analysis of processes occurring in independent Georgia. Academic and political circles share the opinion that the main "culprit" in the destructive processes of post-Soviet Georgia was the intolerant, exclusive Georgian nationalism, which appeared at the dawn of independence. Certainly, Georgian nationalism was an important factor in the period of transition of the 1990s. However, theories of nationalism are insufficient for a thorough study of the issue. ${ }^{13}$ An analysis of the transformation of independent Georgia through the prism of nationalism neglects important tendencies of the development of Georgian society. In order to draw a more or less complete picture, it is necessary to dwell on the concept of "populism," which is widely used on the social and political level. In

13 Jones, Georgia, 217-220. 
contemporary humanities and social sciences, there are diverse opinions regarding the concept of populism. Despite being vague from the academic perspective, the concept of populism is quite flexible and often acquires diverse socialeconomic content. It is revealed in numerous forms within societies in transition, where the degree of awareness of political developments is low and the future is threatening. Populism may be urban, rural, non-liberal, democratic, etc. Different variants of populism may be applied to different social layers. Margaret Canovan offers seven definitions of populism. According to her, populism implies a certain degree of exaltation and appeals to ordinary people; it is always anti-elite and aimed against the dominant ideological narrative. ${ }^{14}$ There are several key features that are common to all types of populism, including the search for scapegoats, such as foreign governments, intellectuals, or ethnic and religious minorities. Populism is also characterized by charismatic power, the cult of the chieftain, emphasis on the nation's fate, and so on. Mass demonstrations, plebiscites, the mobilization of people around a concrete idea - these are major tools of populist policies. ${ }^{15}$ The above-mentioned elements of populism are important tools for the analysis of processes that took place in Georgia after independence.

Out of the numerous types of populism, within the framework of the given research, I will focus on the concept of national populism. This concept implies a close connection between populism and nationalism. Despite certain criticism, the majority of works dedicated to populism recognize the close connection between the two concepts. Moreover, some famous authors put an equation mark between populism and nationalism. Both nationalism and populism put an emphasis on people's sovereignty. In their article, Benjamin de Cleen and Yannis Stavrakakis attempt to explain a widespread idea regarding the connection between populism and nationalism. In their opinion, although the power of a national state as the key decision-maker has weakened, it still remains the main space in democratic political representations and public debates. That is why the connection between populism and nationalism is quite natural. ${ }^{16}$ Ernest Gellner and Ghita Ionescu discuss populism as one of the forms of nationalism. ${ }^{17}$ In the ample theoretical literature, nationalism is viewed as an inalienable part of the populist policy.

14 Margaret Canovan, Populism (New York/London: Harcourt Brace Jovanovich, 1981), 2-13.

15 Jones, Georgia, 77.

16 Benjamin De Cleen and Yannis Stavrakakis, "Distinctions and Articulations: A Discourse Theoretical Framework for the Study of Populism and Nationalism," Javnost - The Public: Journal of the European Institute for Communication and Culture 24, no. 2 (2017): 301-319.

17 Ernest Gellner and Ghita Lonescu, Populism: Its Meanings and National Characteristics (Letchworth: Garden City Press, 1969), 1-5. 
The above research is not aimed at a thorough analysis of debates around the concept of populism. We use this concept for the analysis of the context of processes in independent Georgia. Nationalism, appeals to the people, mass mobilization - these are the tools actively used by politicians and leaders of public organizations in the implementation of populist policies, with the aim of developing diverse national projects.

Another methodological basis of this research is the instrumentalist attitude. According to this attitude, national identities are flexible and changeable in time and environment. Instrumentalist theories are based on the idea that nationalism and ethnicity are the results of various political, economic, and social processes. The majority of contemporary researchers agree that such identities represent social constructs.

The main method used in the given research is discourse analysis. Recently, discourse has become one of the most fashionable terms in scholarly literature. It is widely used in political and intellectual debates. Yet the meaning of discourse is not clearly defined. In general, discourse may be defined as a specific language used in the process of perception of the world, or a viewpoint expressed in a certain field of social life, for instance, medical discourse, political discourse, and so on. Discourse analysis is interdisciplinary research; it forms a framework that can be used in diverse academic disciplines. ${ }^{18}$

I use a content analysis method with regard to the empirical material. The researcher who uses this method is interested in a concrete aspect of the analyzed documents - specific relationships reflected in the document, the author's attitude to this or that issue, and so on. In this case, it is interesting to find out the key tendencies represented in the analyzed factual material regarding attitudes to the West, the key peculiarities of the post-Soviet Georgian national discourse regarding Euro-Atlantic integration.

\section{Georgia's Path to Independence}

To familiarize readers with the situation in Georgia and provide a context of the processes developed at the dawn of independence, a brief review of the country's path to post-Soviet liberalization is provided here.

A new stage of Georgian nationalism started in the late 1980s, which emerged from the dissident movement of the 1970s. In the initial stage, the movement was

18 Marianne Jørgensen and Louise Phillips, Discourse Analysis as Theory and Method (London: Sage, 2002), 12. 
of an environmental character. Measures taken for the protection of Georgia's environment and cultural heritage determined the cultural form of Georgian nationalism from the very beginning. At the same time, a "victory syndrome" appeared in Georgian society due to successful street protest marches. The reins of the national movement appeared to be totally in the hands of radically disposed leaders, whose main tools to achieve their political aim were irreconcilability, manifestations, hunger strikes, and other such activities. Toward the end of the 1980s, the Georgian national movement, which was managed from the street, turned into an emotional phenomenon. The rhetoric, approaches, and decisions of radical leaders were mostly driven not by rationalism but by the emotional background in the streets and at rallies. ${ }^{19}$

From the end of the 1980s, against the background of ongoing processes of restructuring and democratization, the strengthening and upsurge of Georgian nationalism significantly determined the fast pace of Georgia's independence. The Communist government was gradually losing real power and made decisions prompted by the Georgian national movement. The sharp rise of nationalism and ruling nationalist rhetoric restricted the area of activities of the governing elite. Despite the dominance of the nationalist discourse, which was also introduced under the Communist government, the latter still managed to control the situation. However, soon the processes turned into a tragic scenario, which forever deprived the Georgian Communist government of legitimacy.

On 9 April 1989, the Soviet authorities violently dispersed a rally demanding Georgia's independence. After that day, radical leaders entirely took hold of ongoing processes, and Georgian nationalism finally took on a radical form, whose main tools were street protests and manifestations..$^{20}$ The tragedy of 9 April rallied the Georgian population around the idea of independence, but from then on, the national movement split up forever. Its leaders did not have an established and shared position on how to fight for the independence of Georgia. The emotional background and personal misunderstandings between leaders played a great role in this process; reasons for this can be found in the early stages of the development of the national movement.

After the tragedy of 9 April, Georgia, along with the Baltic countries fighting for independence, happened to be in the leading position among the Soviet Socialist Republics. In May of the same year, the leaders of the radical wing of the national movement, having been released from prison, reached the peak of

19 Irakli Chkhaidze, "From Ethnic to Civic Nationalism: The Dynamics of the National Project in Post-Soviet Georgia" (PhD thesis, Tbilisi State University, 2016), 42-47.

20 Jones, Georgia, 31-38. 
their popularity. In order to stabilize the situation, the Soviet leadership made governmental changes: they appointed the head of the Security Committee as the head of the government to replace the previous one, who was discredited. By promoting the person from the security service, the government attempted to restore its control over the situation with its traditional severe methods and a "powerful hand," although the Communist Party had almost lost its legitimacy in the eyes of society. In his turn, the new head of the party had to obey the dominant nationalist moods in the country and take a loyal position toward the national movement. Abuse of the Soviet ideology, Vladimir Lenin, and the central government became common in official and inofficial Georgian discourses. ${ }^{21}$ Parallel to open confrontation with the Soviet ideology, which was declared to be immoral, the national movement itself was overwhelmed with romanticism and was wrapped in the mantle of high moral and ethical ideals.

Finally, national forces came to power via elections. The leading figure of the national movement and Georgia's first president, Zviad Gamsakhurdia (1939-1993), confronted other radical leaders. He founded a political organization called "Round Table - United Georgia" and took part in the elections set up by the Communist government on 28 October 1990, in which Gamsakhurdia and his coalition won a resounding victory.

The elections put an end to the 70-year-long period of Communist rule in Georgia. Gamsakhurdia, one of the biggest adversaries of the Soviet ideology for decades and a former dissident, came to power together with his political coalition. Gamsakhurdia was unanimously elected as the chairman of the Supreme Council. The situation was complicated and controversial as the national government started to rule the country while it was still in the composition of the Soviet Union. The fight for the independence of Georgia thus moved to a new stage. The newly elected Supreme Council had to create a constitutional basis for Georgia's secession from the USSR. The government opposing the central power on the one hand and the national movement inside the country on the other was to face a very hard transition period, which required government officials to get themselves out of their role as national movement leaders and become less radical and more rational. However, the processes in Georgia developed even more dramatically and, finally, escalated into a civil war.

The period of rule of the political coalition "Round Table - United Georgia" did not last long but was full of dramatic events: Georgia was declared independent, the country elected its first president, tensions in the breakaway region of Tskhinvali exacerbated, escalating into an armed conflict, and a civil war sparked

21 Chkhaidze, "From Ethnic to Civic Nationalism," 48-52. 
up in the center of Tbilisi. The so-called "Tbilisi War" resulted in the overthrow of the national government, and the president fled the country.

\section{In Search of the "Lost Glory": The West as "Two-Faced Janus"}

At the end of the 1980s, the process of the disintegration of the Soviet system gave rise to radical Georgian nationalism. The nature of the national movement was largely conditioned by its leader, Zviad Gamsakhurdia. Gamsakhurdia's attitude to Georgia's past, present, and future was sacral and emotional rather than rational. According to him, the Georgian people had suffered for centuries. Finally, the time had come when Georgians would occupy their proper place in the contemporary world. Georgia, as a country with a tragic history, had earned this. ${ }^{22}$ According to Gamsakhurdia, the mission of Georgia was to restore its historical function as the bridge between the West and the East. He paid special attention to religious issues, saying that Georgians had made a special contribution to the development of Christianity. Due to this emphasis on religion, early Georgian nationalism looked irrational. It was nationalism of an exclusive nature, as it was based on the idea of uniqueness. However, the problems that arose at the dawn of independence were not solely due to Gamsakhurdia. His epoch was characterized by economic collapse and the fragmentation and polarization of society. Gamsakhurdia's policy was a mixture of nationalism, populism, religion, and conservatism. According to Jones, like many other leaders of Third World countries, Gamsakhurdia was a product of the imperial system. Although he radically opposed the Soviet regime, he himself often revealed insularity and intolerance - the characteristic features of the Soviet system. ${ }^{23}$

The Georgian national movement and its leader were initially supported by Western states. Later, under the influence of diverse factors, the relationships with the West changed. In August 1991, US President George Bush accused Georgia of fostering ethnic nationalism. In response to this statement, Gamsakhurdia accused Bush of tyranny and supporting communism. Since this period, a dual attitude to the Western world has become widespread in the Georgian public space: the traditional, ancient, “civilized,” moral West was opposed to the contemporary conspiratorial, immoral West. Gamsakhurdia himself thought that Christian

22 Zviad Gamsakhurdia, Spiritual Mission of Georgia (Tbilisi: Ganatleba, 1990), 8-9.

23 Jones, Georgia, 53. 
Georgia had formed part of Western civilization since ancient times. In the contemporary epoch, Georgia was to occupy its due place within the European space. At the same time, Gamsakhurdia actively opposed Western governments who, according to him, played a significant role in the dramatic processes taking place in Georgia. In an interview in 1992, Gamsakhurdia declared:

Western governments aim at the genocide of all other nations, with the exception of one particular group. This group is closely linked to the USA and aspires to domination in the entire world. In fact, I would call it Euro-American Imperialism. Its leading force is the USA. It is obvious that the coup in Georgia was governed by the USA, with the personal support of the Secretary of State J. Baker and with the blessing of President Bush. ${ }^{24}$

In the same interview, Gamsakhurdia added:

There was one more reason for the Western anger towards us. Being at the head of the Georgian State, we aspired for the restoration of the national culture, unification of people under the national spirit, public awareness of the fact that our history is far more ancient than that of the Europeans . . . . Our policy, which was based on the national orientation, irritated the leaders of the European Commonwealth, because the official West (I mean leaders and not ordinary people) struggles against every national movement. Their aim is to eliminate the nation's will and, in general, create a unified conglomerate with World Government. This World Government will rule the universe and establish the so-called new world order. ${ }^{25}$

In Gamsakhurdia's opinion, it was due to the above-mentioned reasons that the “agent of international imperialism” - Eduard Shevardnadze (1928-2014) - came to power after the coup that removed Gamsakhurdia from power.

Despite his anti-Western national populism, we cannot conclude that Gamsakhurdia was a radical opponent of the West. HHis attitudes were quite prone to changing within short periods of time. Besides, we should take into account the fact that Gamsakhurdia considered Shevardnadze as his main enemy and one of the organizers of the coup. Shevardnadze was supported by Western political circles. This caused Gamsakhurdia's discontent and acute anti-Western attitudes.

The dual attitude to the West became widespread in Georgia in the abovementioned period, and its pioneer was Gamsakhurdia. In 1992, in his address to Georgian television, Gamsakhurdia denied accusations regarding his anti-Western isolation policy. He condemned the Western orientation, which implied "the cult of pornographic and sadistic films, the 'heroics' of gangsters, the imitation of Western fashion, begging the West for credits, suspicious political deals with some

24 Zviad Gamsakhurdia, “Interview,” Aghdgoma, December 4, 1992, \#20, 1-2.

25 Ibid. 
political adventurists, the invitation of these adventurists to Georgia, selling off Georgia's natural riches, resorts, ports and industries to the West and so on.” However, according to Gamsakhurdia, "Western culture, civilization, art, political thinking, philosophy, and social and legislative systems are very close to us. Awareness of all this and the formation of an open democratic society - this is what we should mean by Western orientation."26

Such a dualistic attitude to the Western world, which formed a major part of the Georgian public discourse at the beginning of independence, still remains one of the most topical and problematic issues. The idealization of the West on the one hand and, on the other, its demonization are the key characteristic features of Georgia's development since its independence.

\section{Parallel Processes: Official Pro-Western Discourse versus Anti-Western Populism}

In March 1992, the former Minister of Foreign Affairs of the Soviet Union, Eduard Shevardnadze, came to power in Georgia. During his presidency, Georgia's foreign policy became obviously pro-Western. Against the background of their complicated relationships with Russia, the Georgian authorities aspired to enhance their relationships with Western states. Alongside practical steps aimed at Euro-Atlantic integration, pro-Western official rhetoric was enhanced. Shevardnadze described the Western course as the only way for the country to develop. In his opinion, close relationships with the West would help the country achieve stability, overcome poverty, and find its way out of the chaos of the civil war. In 1999, after Georgia joined the European Council, the Chairman of the Georgian Parliament declared, "I am a Georgian, therefore, I am a European.” These words turned into a slogan of the pro-Western political course. ${ }^{27}$

This political course defined Georgia's civil transformation. With the aim of developing state institutions, on 25 March 1993, Shevardnadze's government adopted a new law on citizenship. ${ }^{28}$ When adopting this undoubtedly liberal law, the authorities took into consideration the ethno-political situation in Georgia and granted citizenship to all residents of Georgia. The law did not require any qualifications like the knowledge of the state language or the

26 Zviad Gamsakhurdia, “Address to the Georgian People,” Kartuli Azri, June 1, 1992, \#24, 1.

27 Chkhaidze, "From Ethnic to Civic Nationalism," 106-110.

28 "Law on Citizenship" (1993), accessed March 31, 2020, http://mra.gov.ge/res/docs/ 2013110412031013274.pdf. 
history of Georgia. This Law on Citizenship was far more liberal than that of numerous democratic European states.

Another significant act, which finally defined the inclusive civil nature of the Georgian national project, was the Georgian Constitution, adopted on $24 \mathrm{Au}$ gust 1995. The preamble of the Constitution expresses the will of Georgia's citizens to establish democratic order, ensure human rights and freedoms, reinforce state independence, establish peaceful relationships with other nations, and so on. 29

Since the "Rose Revolution" of 2003, the civil discourse on national identity and Western aspirations have been further enhanced in Georgia. During the presidency of Mikheil Saakashvili, European ideas and the development of a Western state became the main components of the national project. The idea of Georgians being the most ancient Europeans was revived (albeit in a different form from Gamsakhurdia's epoch). Saakashvili's speech from 2013 proves that the authorities considered Western orientation as the key direction of the Georgian national project. According to Saakashvili, a nation is a project which defines its society's present and future. “A project which unites us without regard to our political, social, religious, ethnic or regional differences. A nation is not ethnicity, and it cannot be solely based on common history. Thus, ladies and gentlemen, a nation is a national project," declared Saakashvili in the abovementioned speech. He also defined the key components of the national project independence, sovereignty, territorial integrity, democracy, economic development, and European integration. He noted that, in the event that any of the above-mentioned components are damaged, the entire building would be destroyed. ${ }^{30}$

The current government of Georgia also supports the Western orientation. In the past years, the country has achieved significant success on the way to Western integration, such as the EU Association Agreement, signed in June 2014, and the Agreement on Visa Liberalization, signed in 2017, which entails the visafree entry of Georgian citizens into Schengen countries.

Despite the above-mentioned successes, the "Westernizing" tendency of official policies is developed against the background of the demonization of the West by certain social groups. The steps made on the path to European integration, especially adaptation of the Western legislative basis, have been opposed

29 “Constitution of Georgia” (1995), accessed March 31, 2020, http://www.parliament.ge/ge/ kanonmdebloba/constitution-of-georgia-68.

30 Mikheil Saakashvili, “Address to the People” (2013), accessed March 31, 2020, http://trade bridgeconsultants.com/news/government/president-mikheil-saakashvili-delivers-annual-address-innational-library/. 
by part of Georgian society. For instance, a law adopted in 1999, which implied the extraction of the nationality column from identity cards, was condemned by certain social organizations and politicians. Guram Sharadze, Chairman of the Parliamentary Committee of Immigration, declared: "If we neglect nationality, in several years we will no longer know whether Georgians form a majority among the 80 nationalities and ethnicities residing in Georgia. And if we no longer know whether we represent a majority, we may also question whether our State should still be called Georgia. People will say: if Georgians do not represent a majority of the population, why should this country be called Georgia?" According to Sharadze, Georgia has turned into a polygon of cosmopolitanism. Nations with a much shorter history of existence are teaching Georgians how to be tolerant and respect human rights. According to Sharadze, the USA was such a nation. $^{31}$

In Georgia, contemporary Western values are often criticized by well-known people. One of the representatives of the Georgian business elite, Levan Vasadze, is an active continuer of the vision developed at the beginning of the 1990s. He makes a radical difference between good and bad Europe:

I am one of the first apologists of Europe and the West. However, I have the impression that historical Europe is one thing and contemporary European culture is another thing. I have nothing to do with the Europe in which homosexual marriage is allowed. I do not want my wife, children and friends to be part of such a Europe. If the Europeans say: "This is our standard and, if you want to join us, become like that," we will answer: "Sorry, we thought Europe was something else." 32

Two years ago, representatives of the cultural field disseminated a letter in which they addressed the diplomatic corps and the international organizations accredited in Georgia. The authors of the letter accused the Western states of being responsible for Georgia's poverty, territorial disintegration, and demographic problems. According to the authors, all these problems arose as a result of Georgia's pro-Western course and aspiration to NATO. The letter says: "ProWestern policy and Georgia's aspiration to NATO have complicated Georgia's relationships with its neighbor Russia. This has led to Georgia's territorial disintegration and social-economic problems, hampered the country's development, caused poverty and reduced the population to less than 4 million." According

31 Guram Sharadze, “Interview” (1999), accessed March 31, 2020, https://guramsharadze. wordpress.com/devnili/erovnebis-rekviziti/.

32 Levan Vasadze, “Interview” (2013), accessed March 31, 2020, https://www.kvirispalitra.ge/ politic/17206-levanvasadzeim-?all=1\&add_new=0\&reply=0. 
to the authors, Georgia, which is a country with ancient history and culture, has never betrayed its allies, unlike the North Atlantic Alliance. ${ }^{33}$

Georgian public space, television, and social and printed media form a kind of battlefield for pro-Western and anti-Western counter-narratives. Recently, anti-Western attitudes have become orderly and purposeful, having penetrated into the highest political bodies, namely, the Parliament. In the elections of 2016, the ultra-nationalist, anti-Western political union "Alliance of Patriots" won a number of seats in the Parliament. The coalition's leaders openly expressed their negative attitude toward Georgia's Western orientation.

Anti-Western populism in Georgia is largely based on negative stereotypes. It appeals to such sensitive and vulnerable topics as territorial disintegration, Orthodox Christian religion, socio-economic issues and poverty, traditional values, family, relationships between sexes, etc.

According to Jondi Baghaturia, one of the leaders of the anti-Western political wing, Georgians have not obtained any benefits as a result of nearly 30 years of pro-Western orientation. Only the political establishment has become richer, while a major portion of the population is suffering. The country has lost territories, and the prospects of their reintegration are becoming vaguer and vaguer. According to Baghaturia, the Russian aggression against Georgia is just an answer to the latter's pro-Western policy, and Georgia would not have fallen victim to this aggression if not for this policy. Baghaturia accuses Western states of being responsible for the hardships affecting Georgia since its independence and also notes that the West has been indifferent to Georgia's problems all this time. ${ }^{34}$

"Where do we want to penetrate? Into NATO or into Sokhumi?"35 asked opposition MP Ada Marshania while referring to prospects of the territorial reintegration of Georgia. She noted that Georgians must make a choice between the restoration of territorial integrity and Euro-Atlantic integration. The decision to join a Western organization a priori means the rejection of lost territories. ${ }^{36}$ The former Chair of the Georgian Parliament, Nino Burjanadze, has also made similar

33 "Letter of Cultural Workers" (2018), accessed March 31, 2020, https://for.ge/index.php/ view/50907/kulturis-muSakebis-werili-romelmac-sazogadoebaSi-didi-aJiotaJi-gamoiwvia. html.

34 Jondi Baghaturia, “Interview” (2017), accessed March 31, 2020, https://www.myvideo.ge/v/ 3237062.

35 The capital of Abkhazia, a breakaway region of Georgia occupied by the Russian Federation.

36 Ada Marshania, "What do we want from NATO and the EU," December 31, 2016, Video, 1:37, https://www.youtube.com/watch?v=aBOqnC1QZMY. 
declarations. According to her, the lost territories should be viewed as a price paid by Georgia in return for its membership of Western organizations. It should be noted that Burjanadze was one of the leaders of the "Rose Revolution." While Chair of the Georgian Parliament, she actively made pro-Western statements. After the conflict with President Saakashvili, she moved to the opposition. Since then, she has been trying to take advantage of anti-Western public attitudes and the disappointment of some Georgians in the Western states. ${ }^{37}$

\section{Conclusion}

Since Georgia's independence, the issue of her relationships with the West has turned into a key problem for Georgian society. An analysis of the empirical material has enabled us to distinguish two radically opposed and, at the same time, interrelated tendencies, widespread in the past decades. The relationship of Georgia with the West is characterized by official closeness, a pro-Western political course, attempts at an adaptation with the Western space, and certain achievements in this regard. On the other hand, the closer the country becomes to the West, the more enhanced and organized anti-Western populism is. Demonization of the West takes place parallel to its political idealization and gradually influences the part of the population that is dissatisfied and disappointed with Georgia's Western-oriented policy.

Speaking of anti-Western populism and its influence, we should take into consideration the following factors:

1. Georgians have often been disappointed with Georgian-Western relationships. This disappointment has frequently been caused by exaggerated expectations on the part of Georgians regarding their integration with Western organizations and the interference of the West in the processes taking place in Georgia. This disappointment has created a certain space, which is filled with anti-Western populism. Ideologists of this populism manipulate the abovementioned problem and try to take advantage of the anti-Western attitudes that are widespread in society.

2. Georgia's post-Soviet transformation was characterized by dramatic events. In processes of transition, when state institutions are weak, there are frequent cases of identity crisis, despair, nostalgia for a glorious past, and ultra-

37 Nino Burjanadze, "People must decide - Abkhazia and Samachablo or NATO," November 18, 2014, Video, 9:18, https://www.youtube.com/watch?v=mQaOkms6A3s. 
nationalist attitudes. The environment is favorable for populist politicians and public figures, hence they manipulate public opinion.

3. Georgia's Soviet experience plays an important role because a major portion of society has long lived in conditions of anti-Western propaganda. These people, including representatives of the former Soviet intelligentsia, are emotionally close to the Russian space and feel nostalgic about the Soviet past. Thus, this group assesses Georgia's Western orientation negatively.

4. Another important factor is Georgia's longstanding isolation from the West. In fact, Georgians discovered the Western world only in the past decades. In Georgian society, there are numerous negative stereotypes and prejudices regarding the West. These prejudices are chiefly connected with the Western lifestyle and vision. Along with other factors, this fact is due to the lack of information about the West. Anti-Western organizations actively manipulate these factors; moreover, they themselves create numerous negative stereotypes.

5. Lastly, we should emphasize the factor of Russia, which views the EuroAtlantic organizations in the Caucasus as the main threat to its interests. Anti-Western populism is actively supported by pro-Russian political and public organizations in Georgia. These organizations appeal to the idea of common religion and longstanding close relationships between Georgia and Russia. The role of Russia in the above-mentioned processes is far greater than we have discussed in the given paper. This is an issue that deserves a separate discussion, and, at this stage, it is not part of this article's aims.

The present contribution has analyzed the key factors and tendencies of Georgia's attitudes toward the West since the country's independence. Numerous important issues have been left out at this stage, but these issues are planned to be analyzed during further research.

\section{Works Cited}

Baghaturia, Jondi. “Interview.” Filmed April 2017. Video, 2: 43. https://www.myvideo.ge/v/ 3237062.

Barrington, Lowell W. "Nationalism \& Independence." In After Independence: The Making and Protection of the Nation in Postcolonial and Postcommunist States, edited by Lowell W. Barrington, 3-30. Michigan: University of Michigan Press, 2006.

Brisku, Adrian. "So Far and Yet So Near. The Image of Europe in Georgia: A History of Ideas." May 5, 2017. https://ge.boell.org/ka/2017/05/05/ase-shors-da-mainc-ase-axlos-evropissaxe-xati-sakartveloshi-ideata-istoria.

Brubaker, Rogers. Ethnicity without Groups. Cambridge, MA: Harvard University Press, 2006. 
Burjanadze, Nino. "People must decide - Abkhazia and Samachablo or NATO!” November 18, 2014. Video, 9:18. https://www.youtube.com/watch?v=mQaOkms6A3s.

Canovan, Margaret. Populism. New York/London: Harcourt Brace Jovanovich, 1981.

Canovan, Margaret. The People. Cambridge: Polity Press, 2005.

Chkhaidze, Irakli. "From Ethnic to Civic Nationalism: The Dynamics of the National Project in Post-Soviet Georgia.” PhD Thesis, Tbilisi State University, 2016.

Coene, Frederik. Euro-Atlantic Discourse in Georgia: The Making of Georgian Foreign and

Domestic Policy After the Rose Revolution. London/New York: Routledge, 2016.

Constitution of Georgia. 1995. Retrieved from http://www.parliament.ge/ge/kanonmdebloba/ constitution-of-georgia-68.

De Cleen, Benjamin and Yannis Stavrakakis. "Distinctions and Articulations: A Discourse Theoretical Framework for the Study of Populism and Nationalism." Javnost - The Public: Journal of the European Institute for Communication and Culture 24 (2017): 301-319.

Gamsakhurdia, Zviad. “Address to the Georgian people.” Kartuli Azri 24, 1992.

Gamsakhurdia, Zviad. “Interview.” Aghdgoma 20, 1992.

Gamsakhurdia, Zviad. Spiritual Mission of Georgia. Tbilisi: Ganatleba, 1990.

Gellner, Ernest and Ghita Lonescu. Populism: Its Meanings and National Characteristics. Garden City Press, 1969.

Jones, Stephen F. "Georgia: Nationalism from under the Rubble." In After Independence: The Making and Protection of the Nation in Postcolonial and Postcommunist States, edited by Lowell W. Barrington, 248-276. Ann Arbor, MI: University of Michigan Press, 2006.

Jones, Stephen F. Georgia: A Political History since Independence. London: I.B. Tauris, 2013. Jones, Stephen F. Socialism in Georgian Colors: The European Road to Social Democracy, 1883-1917. Cambridge, MA: Harvard University Press, 2005.

Jørgensen, Marianne and Louise Phillips. Discourse Analysis as Theory and Method. London: Sage Publications, 2002.

Kakitelashvili, Tamar. "The West in the Georgian Consciousness." Language and Culture 1 (2000): 47-54.

Law on Citizenship. 1993. Retrieved from http://mra.gov.ge/res/docs/2013110412031013274.pdf.

Letter of Cultural Workers. 2018. Retrieved from https://for.ge/index.php/view/50907/kultu ris-muSakebis-werili-romelmac-sazogadoebaSi-didi-a)iotali-gamoiwvia.html.

Marshania, Ada. "What do we want from NATO and the EU." December 31, 2016. Video, 1: 37. https://www.youtube.com/watch?v=aBOqnC1QZMY.

Moffitt, Benjamin. The Global Rise of Populism: Performance, Political Style, and Representation. Stanford: Stanford University Press, 2016.

Nodia, Ghia. "The Idea of the West in the Georgian Consciousness." In Society and Politics 2 (1999): 35-74.

Saakashvili, Mikheil. “Address to the People.” 2013. http://tradebridgeconsultants.com/news/ government/president-mikheil-saakashvili-delivers-annual-address-in-national-library/.

Sharadze, Guram. “Interview.” 1999. https://guramsharadze.wordpress.com/devnili/erovne bis-rekviziti/.

Suny, Ronald Grigor. The Making of the Georgian Nation. 2nd ed. Bloomington, IN: Indiana University Press, 1994.

Vasadze, Levan. “Interview.” 2013. https://www.kvirispalitra.ge/politic/17206-levanvasad zeim-?all=1\&add_new=0\&reply=0.

Wheatley, Jonathan. Georgia from National Awakening to Rose Revolution: Delayed Transition in the Former Soviet Union. London/New York: Routledge, 2005. 